Article

\title{
Green Management Tools as a Way to Sustainable Behaviour in the Hotel Industry: Case Study from Czechia
}

\author{
Petr Scholz ${ }^{1, * \mathbb{D}}$, Ivica Linderová ${ }^{1}$ and Kristýna Konečná ${ }^{2}$ \\ 1 Department of Travel and Tourism, College of Polytechnics Jihlava, Tolstého 16, \\ 58601 Jihlava, Czech Republic; ivica.linderova@vspj.cz \\ 2 Primary School Tišnov, Nám. 28, Října 1708, 66601 Tišnov, Czech Republic; kristyna.konecna@tisnov-zs28.cz \\ * Correspondence: petr.scholz@vspj.cz; Tel.: +420-567-141-136
}

Received: 29 October 2020; Accepted: 27 November 2020; Published: 1 December 2020

\begin{abstract}
Sustainability has long been a buzzword and is also currently one of the major priorities of tourism all over the world. In many places, hotels function as a driving force for socio-economic development, serving as employers for the local population, but also providing space for meetings, conferences, private/family events, and ceremonies. Unfortunately, the hotel industry is also considered an industry characterized by the consumption of considerable amounts of resources. These include mainly energy and water consumption, but also waste production. Emphasis is placed on the role of the communication between the various players involved in the operation of hotels. The article deals with applying elements of green management in a selected hotel in Czechia. It analyses the implementation of green management elements and principles of sustainable development in accommodation services. The primary data were conducted from April 2017 to March 2018 and we used structured and semi-structured interviews with the TOP management of the hotel and by author observation. We used the methods of scientific work, i.e., the analysis, mathematical, and statistical methods. As part of economic and social activities, cooperation with suppliers in the close surroundings of the hotel and the selection of local employees work well. Room for improvement has been observed, e.g., in supporting local infrastructure or promoting environmentally friendly types of transport.
\end{abstract}

Keywords: accommodation facility; environmental certification; environmental measures; green management; hotel industry; Czechia

\section{Introduction}

The impact of global tourism growth on the environment has become an important topic in the hotel industry. Most foreign hotel guests are beginning to gain an environmental awareness and feel that accommodation establishments should be more involved in sustainable practices [1]. It is environmentally friendly products or services that have achieved considerable success in response to guests' increased sensitivity arising from concern about the constantly deteriorating environment [2]. We note that statistics reveal an upward trend in green consumerism over the past few years [3]. The importance of social responsibility of companies for business and society is considered an important factor for sustainable growth [4]. Closer collaboration with stakeholders will allow hotels and restaurants to cast a wider net and tap into a broader reservoir of resources and partnerships [5]. Therefore, many business leaders are developing sustainability plans and programs as an increasingly important component of their corporate strategy. There are several factors that help to explain this trend. They include an ever growing number of directives and regulations on environmental and social issues, concerns about the growing lack of vital natural resources, increasing awareness of shareholders 
in terms of the importance of ethically substantiated corporate investments, and intense pressure from the press and television regarding anti-corporate and anti-capitalist organizations and pressure groups. An ever growing number of large companies now want to publicly show and demonstrate their commitment to sustainability and development in the field of sustainability in order to increase their competitive advantage, build their brand, and differentiate themselves from their competitors within the market [6]. At the same time, some perceive corporate commitments to sustainability and development in this area as an inconsiderate manoeuvre, or so-called greenwashing [7]. This is a process where the company publicly and falsely declares that it is environmentally friendly, while internally participating in environmentally unfavourable practices. This term is therefore used mainly in situations where more effort and resources have been expended to present a green approach than to fulfil the facts. The word itself reminds us of the word "brainwashing". The term greenwashing allegedly originated in 1983 from washing towels. The first person to use this term was Jay Westervelt, who was once accommodated in a hotel with hotel cards convincing the guests to use towels repeatedly (the practice is that a maid always changes the towels). Westervelt calculated that there is no difference between washing fewer towels and more towels. The washing machine must be switched on, the water consumption per cycle is quite the same and the towel must always be ironed anyway. Westervelt realized that this was a mere trick to simply impose on guests the idea of a responsible approach to the environment, even if it could ultimately affect client loyalty [8]. Greenhushing, the converse of greenwashing, is the deliberate withholding, from hotel guests and stakeholders, of information about the sustainability practices that they employ. We suggest that hotels use greenhushing to mitigate a potential disconnection between their perception of guest expectations and their own operational position concerning sustainability issues [9].

\section{Literature Review}

Half of humanity lives in cities and that proportion keeps growing. By 2030, the share of the urban population will be almost $60 \%$. Cities cover only $2 \%$ of the Earth's surface but consume $60-80 \%$ of all energy and generate up to $75 \%$ of greenhouse gas emissions. Green infrastructure is considered a factor in the sustainable development of a city [10]. Rapid urbanization exerts pressure on drinking water supplies, sewerage, the environment, and the health system. However, a high concentration of people in cities can also lead to more efficient use of resources and energy and to technological innovations that will help reduce their consumption. Some cities are powered by solar energy and accommodation facilities themselves contribute to this as well. Although individual accommodation facilities affect only a small part of the global environment, they can contribute to resolving major global environmental problems to some extent. These include global warming caused by the production of greenhouse gases, depletion of the ozone layer, which is threatened mainly by chlorofluorocarbons, acid rains, the creation of which is supported by the burning of high sulphur content fossil fuels and the over-exploitation of non-renewable energy sources such as oil and coal. Environmental protection is currently a topic that is receiving a great deal of attention not only in practice but also in academia and is discussed in all areas of life. Efforts to minimize negative impacts on the environment are also reflected in the hotel industry, namely in the form of green management. This is what we call the philosophy, technology, and management methodology of an organization that focuses on optimizing the impact of its operations on the environment. Also, due to the construction of new accommodation facilities, the habitat for local fauna and flora is being reduced, therefore, the eco-friendly approach has become more urgent in order to mitigate the negative impact on the environment, too [11]. The main goals are economical handling of materials, energy, and other resources, economical operation, and the reduction of environmental factors. Last but not least, another advantage is differentiation from the competition. To stay within the safe boundaries of global warming, the world now has 30 years to decarbonize its economy. This represents a fundamental challenge for tourism as a growth system (e.g., mitigation carbon taxes, weather extremes, or black swan events, e.g., COVID-19 pandemic), [12]. 
A guest can choose between two types of accommodation facilities which focus on the application of green management steps. The first type is accommodation facilities that have been able to meet the demanding criteria for environmental certification with their operation and subsequently obtained it. The second group of accommodation facilities consists of environmentally active and environmentally friendly buildings which apply countless elements of green management, but do not have an environmental certificate due to financial indisposition [13]. This means that a hotel does not necessarily have to be certified in order to be environmentally active and help to improve the quality of the environment in its surroundings. Through these activities, it can increase guests' awareness of green management and thus generally increase the demand for environmental elements in accommodation facilities. Currently, there are five such accommodation facilities in Czechia, which represents only $0.053 \%$ of the total number of 9383 accommodation facilities. On the other hand, the laws or regulations of most countries do not have a legal or a universally accepted definition of what is a "green accommodation facility or eco-friendly hotel". It means that the practice of using "green or eco-friendly" as a marketing ploy is still widespread in many cities and towns around the world. A lot of hotel managers are claiming that they are "green or environmentally friendly" by simply hanging a sign and declaring themselves to be green [14].

Hotels try to be more socially responsible, taking environmental initiatives in areas such as practices related to clean air, recycling (waste reduction), and energy efficiency [15]. A key finding is that many hotels and restaurants are not actively innovating in the waste domain. They are, however, increasingly aware of the economic and social importance of waste management [16]. Hotel owners also appreciate the numerous benefits of environmental practices, better company image and contributing to the sustainable development of tourism [1]. Hotels and restaurants focusing on eco-friendly practices should consider implementing a combination of innovation types (service, process, marketing, and organizational learning) that yield an increase in performance $[17,18]$. On the other hand, implementing the sustainable practice of specific new green procedures and measures requires significant investments, and only some of them may, in the long-run context, translate into lower operating costs. Investments in green initiatives are the result of the growing awareness of environmental protection. Potential economic savings are secondary effects, but not the most important benefit. The economic impacts of using green management tools are not very significant in the context of the overall hotel economy.

A number of environmental protection measures are aimed at reducing the consumption of energy [1,19-22], water [23-26], chemical agents, and office supplies, reducing the amount of waste, increasing the use of natural materials, the aestheticization of the environment, reducing noise pollution, emissions, etc. [27-34]. There are a number of ways of going green. We can see that in practice accommodation facilities adopt various approaches in choosing environmental protection measures. Owners of accommodation facilities and hotel managers are not the only ones worried about the environmental issues. Due to the increased awareness and advanced green technologies such as nontoxic pest control, stormwater systems, and energy-saving systems for properties, accommodation facilities are able to diversify their environmental practices [35]. Some decide based on what is most urgent at the time, others focus on measures that result in the greatest reduction in resource usage at the lowest cost. Environmental responsibility takes on a lot of forms, including power management or recycling procedures, switching off lights, watching the use of air-conditioning units or waste recycling [36]. They should also, in a friendly manner, raise their guests' environmental awareness [37]. Essential tasks include sorting waste and multiple reuse of recycled materials.

In addition to environmental activities, economic and social activities are also an important part of green management (Table 1). These areas include support for local infrastructure, purchase of raw materials and products from within the region, the use of public transportation and bicycles, hiring of locals, etc. [38]. Hotels prefer buying raw materials and products from local vendors to importing them from more distant locations or exotic products from abroad. This element of green management is reflected primarily in the hotel kitchen. In practice, this may mean that a hotel 
restaurant in a Czech town will not specialize in sea fish imported from abroad but will instead offer freshwater fish, especially if there is a supply from local ponds. This method has several benefits. For an authentic experience guests have a chance to taste the local gastronomy. Another advantage is that products imported from the vicinity of the hotel are fresh, transport costs are lower, and local businesses are supported, thus raising the local standard of living. Hotels rely on networks of internal and external relations. The way they are managed is often crucial to the success of the entire hotel. Sharing experience and information with suppliers, guests, like-minded hotels, and local business organizations can increase hotel prosperity. A business's success depends on various qualities of employees' knowledge, skills, talent, innovative creativity, and much more. That is why employee motivation is significant. We should also point out food waste in tourism enterprises. Hotel food waste is a growing global challenge whose mitigation requires the commitment of multiple stakeholders. On the other hand, guest awareness of hotel food waste is growing, which underlines the policy-making and managerial importance of understanding how hotel guests can be encouraged to engage in more active hotel food waste prevention and mitigation [39].

Accommodation facilities also invest resources in energy efficient lighting, which can result in significant savings [40]. Another advantage of the compact fluorescent lamps is that they have a considerably longer service life, which reaches an average of $6000 \mathrm{~h}$ of lighting. However, they are currently increasingly coming to the forefront of LED technology (light emitting diode). Compared to the common light sources, their durability is much higher. However, it should not be installed at the places where there is frequent switching off lights. What is more, the lifetime of LED lamps is in the range 30,000 to $100,000 \mathrm{~h}$ of lighting, but the product which promises life of 100,000 $\mathrm{h}$ are often not very reliable. The usual lifetime of LED lamps is around 30,000 h, but it may also be lower or higher (Table 2).

Table 1. Hotel sustainability performance indicators.

\begin{tabular}{|c|c|c|}
\hline $\begin{array}{c}\text { Economic } \\
\text { Performance }\end{array}$ & Environmental Performance & $\begin{array}{c}\text { Social } \\
\text { Performance }\end{array}$ \\
\hline $\begin{array}{l}\text { - } \quad \text { hotel revenues } \\
\text { operating costs (implementation } \\
\text { of ISO 14001, Eco-Management } \\
\text { and Audit Scheme) } \\
\text { hotel profits (purchasing larger } \\
\text { volumes and minimizing } \\
\text { packaging and products that the } \\
\text { hotel really needs, purchasing } \\
\text { products from suppliers in the } \\
\text { region, purchasing quality and } \\
\text { truly useful products, purchasing } \\
\text { of environmentally friendly } \\
\text { products, and measuring } \\
\text { guests'satisfaction) } \\
\text { employee compensation } \\
\text { donations and other } \\
\text { community investments } \\
\text { retained earnings } \\
\text { payments to capital providers } \\
\text { and governments } \\
\text { proportion of spending on } \\
\text { locally-based suppliers (purchase } \\
\text { of raw materials and products in } \\
\text { the region, support } \\
\text { local infrastructure) } \\
\text { corporate philanthropy }\end{array}$ & $\begin{array}{l}\text { total direct and indirect } \\
\text { greenhouse gas emissions } \\
\text { energy consumption by primary } \\
\text { source (regulating heating and } \\
\text { air conditioning, thermal } \\
\text { insulation of buildings) } \\
\text { energy saved through } \\
\text { conservation and efficiency } \\
\text { improvements (low energy } \\
\text { technologies, appliances min. } \\
\text { class A (A +, A ++, A+++), } \\
\text { compact fluorescent lamps) } \\
\text { initiatives to reduce energy } \\
\text { consumption (utilization of } \\
\text { geothermal energy and } \\
\text { waste heat) } \\
\text { total water consumption } \\
\text { (installation of single-lever } \\
\text { mixers and faucet aerators, } \\
\text { energy-saving shower heads, and } \\
\text { two-stage flush toilets) } \\
\text { total water recycled and reused } \\
\text { (grey-water reuse, } \\
\text { rainwater harvesting) } \\
\text { waste output (waste separation } \\
\text { in the background of hotels, } \\
\text { sorting bins for plastic, paper, etc. } \\
\text { in each room, reuse recycled } \\
\text { materials, composting } \\
\text { organic waste) }\end{array}$ & 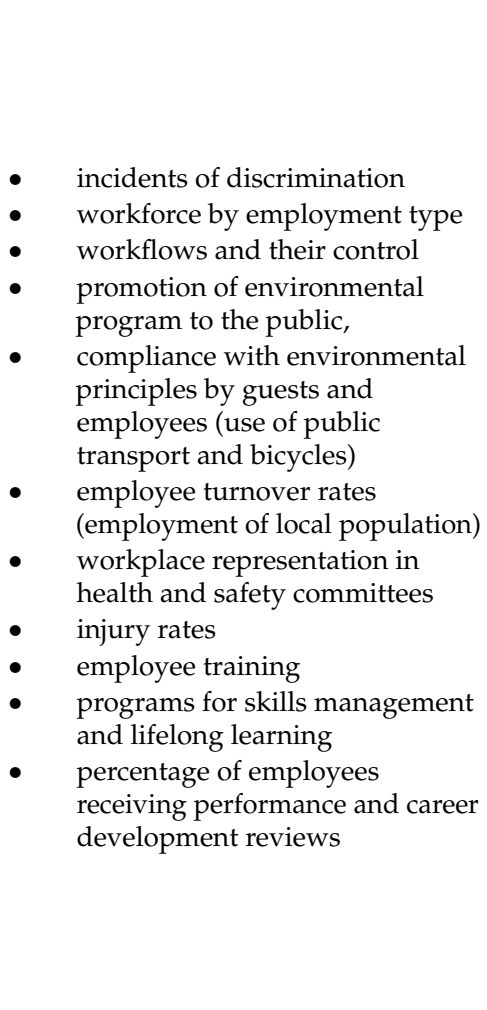 \\
\hline
\end{tabular}


Table 1. Cont.

\begin{tabular}{|c|c|}
\hline $\begin{array}{c}\text { Economic } \\
\text { Performance }\end{array}$ & Environmental Performance \\
\hline Indicators Benefits & Indicators Costs \\
\hline $\begin{array}{ll}\text { - } & \text { monetary } \\
\text { - } & \downarrow \text { energy costs } \\
\text { - } & \downarrow \text { wrevaste and water costs } \\
\text { - } & \uparrow \text { profits } \\
\text { - } & \uparrow \text { other operational savings } \\
\text { - } & \text { non-monetary } \\
\text { - } & \downarrow \text { greenhouse gas and } \\
& \text { pollutant emissions } \\
\text { - } & \uparrow \text { biodiversity conservation } \\
\text { - } & \uparrow \text { employee health } \\
& \text { and productivity }\end{array}$ & $\begin{array}{l}\text { - } \quad \text { investments in environmental management initiatives } \\
\text { - } \quad \text { investments in economic performance initiatives } \\
\text { - } \quad \text { investments in social engagement initiatives } \\
\quad \text { investments in stakeholder reporting }\end{array}$ \\
\hline
\end{tabular}

Notes: $\downarrow$ decrease, $\uparrow$ increase. Source: Processed by the International Tourism Partnership.

Table 2. Lights and their efficiency.

\begin{tabular}{|c|c|c|c|}
\hline $\begin{array}{c}\text { Light Properties/Type } \\
\text { of Light }\end{array}$ & $\begin{array}{l}\text { Classic Incandescent } \\
\text { Light Bulb }\end{array}$ & $\begin{array}{l}\text { Compact Fluorescent } \\
\text { Light Bulb }\end{array}$ & $\begin{array}{c}\text { LED } \\
\text { Light Bulb }\end{array}$ \\
\hline Wattage & $40 \mathrm{~W}$ & $11 \mathrm{~W}$ & $5 \mathrm{~W}$ \\
\hline Price & $€ 0.60$ & $€ 4.80$ & $€ 12.00$ \\
\hline Lifetime & $1000 \mathrm{~h}$ & $6000 \mathrm{~h}$ & $30,000 \mathrm{~h}$ \\
\hline $\begin{array}{c}\text { Hours of operation } \\
\text { annually } \\
\text { (5 h of operation daily) }\end{array}$ & $1825 \mathrm{~h}$ & $1825 \mathrm{~h}$ & $1825 \mathrm{~h}$ \\
\hline $\begin{array}{c}\text { Energy consumption in } \\
\text { kWh annually } \\
\text { (5 h of operation daily) }\end{array}$ & $73 \mathrm{kWh}$ & $20.075 \mathrm{kWh}$ & $9.125 \mathrm{kWh}$ \\
\hline $\begin{array}{l}\text { Lighting costs annually } \\
\quad(1 \mathrm{kWh}=€ 0.20)\end{array}$ & $€ 14.60$ & $€ 4.015$ & $€ 1.825$ \\
\hline $\begin{array}{c}\text { Energy savings in } € \\
\text { annually }\end{array}$ & - & $€ 10.585$ & $€ 12.775$ \\
\hline $\begin{array}{l}\text { Return on investment on } \\
\text { fluorescent light bulbs }\end{array}$ & - & 165.52 days & 342.86 days \\
\hline $\begin{array}{l}\text { Savings over the lifetime } \\
\text { of a fluorescent light bulb }\end{array}$ & - & $€ 34.80$ & $€ 210.00$ \\
\hline
\end{tabular}

Source: Authors' own elaboration, 2020.

Energy and water consumption are currently a very topical issue, which is why accommodation facilities also deal with this problem. Based on the analysis of energy efficiency, innovative measures applied by hotel chains have been classified as follows: (1) celebration of Earth Hour, (2) techniques that reduce energy and hot water usage, (3) energy sources to power properties, (4) energy-efficient appliances, equipment, and infrastructure, (5) effective energy control and management, and (6) energy efficient systems [41]. Water and energy consumption indicators for certain groups of hotels are listed in Table 3 [42]. 
Table 3. Indicators of water and energy consumption in selected groups of hotels

\begin{tabular}{|c|c|c|c|c|}
\hline Indicator & Good & Satisfactory & Unsatisfactory & Poor \\
\hline \multicolumn{5}{|c|}{ A small hotel (4-50 rooms) } \\
\hline Electricity $\left(\mathrm{kWh} / \mathrm{m}^{2}\right.$ per year $)$ & $<60$ & $60-80$ & $81-100$ & $>100$ \\
\hline Gas, oil, steam $\left(\mathrm{kWh} / \mathrm{m}^{2}\right.$ per year $)$ & $<180$ & $80-210$ & $211-240$ & $>240$ \\
\hline Combined $\left(\mathrm{kWh} / \mathrm{m}^{2}\right.$ per year) & $<240$ & $240-290$ & $291-340$ & $>340$ \\
\hline Water (litres per guest per night) & $<330$ & $330-380$ & $381-440$ & $>440$ \\
\hline \multicolumn{5}{|c|}{ A medium-sized hotel (50-150 rooms) } \\
\hline Electricity $\left(\mathrm{kWh} / \mathrm{m}^{2}\right.$ per year $)$ & $<70$ & $70-90$ & $91-120$ & $>120$ \\
\hline Gas, oil, steam $\left(\mathrm{kWh} / \mathrm{m}^{2}\right.$ per year $)$ & $<190$ & $190-230$ & $231-260$ & $>260$ \\
\hline Combined $\left(\mathrm{kWh} / \mathrm{m}^{2}\right.$ per year $)$ & $<260$ & $260-320$ & $321-380$ & $>380$ \\
\hline Water (litres per guest per night) & $<440$ & $440-500$ & $501-600$ & $>600$ \\
\hline \multicolumn{5}{|c|}{ A large hotel (more than 150 rooms) } \\
\hline Electricity $\left(\mathrm{kWh} / \mathrm{m}^{2}\right.$ per year $)$ & $<165$ & $165-200$ & $201-250$ & $>250$ \\
\hline Gas, oil, steam $\left(\mathrm{kWh} / \mathrm{m}^{2}\right.$ per year) & $<200$ & $200-240$ & $241-300$ & $>300$ \\
\hline Combined $\left(\mathrm{kWh} / \mathrm{m}^{2}\right.$ per year $)$ & $<365$ & $365-440$ & $441-550$ & $>550$ \\
\hline Water (litres per guest per night) & $<600$ & $600-700$ & $771-880$ & $>880$ \\
\hline
\end{tabular}

Source: Authors' own elaboration based on Kirk, 1996; 2020.

In general, we can say that large hotel companies (e.g., Wyndham, Marriott, Hilton, etc.) are more active in their care for the environment because they have a more visible impact on it [43], they have more funds available, which they can invest in environmental protection [44], they use the savings resulting from repeated use, they recycle or value waste [45], and they accept stronger pressures to participate in environmental care from various stakeholders. The Hilton hotel chain program called "My Care!" serves as an example of successful environmental management involving effective environmental practices [46]. Between 2009 and 2015, 70 Hilton hotel properties in continental Europe were able to reduce their energy consumption per square meter by $17 \%$, water consumption by $16.7 \%$ and $\mathrm{CO} 2$ emissions per guest by $23 \%$, and more than 16,000 employees were educated and involved in environmental practices over three years. Another hotel chain, Marriott, state that through their "Spirit to Preserve" program, they have been able to reduce energy consumption by $11 \%$, greenhouse gas emissions by $10.7 \%$, and water consumption by $8.2 \%$ per available room over two years [47]. In addition to initiatives in the fields of energy and water savings, waste reduction, recycling and reuse, building of infrastructure, community education, and environmental education, credible certification programs are coming to the fore [48]; these include programs such as Green Seal, Leadership in Energy and Environmental Design (LEED), Green Key, Green Leaf, The Green Tourism Business Scheme (GTBS), the Flower, etc., which are increasingly being promoted by hotel owners around the world. These certification programs require hotels to observe strict environmental practices and initiatives and help to build credibility in the eyes of consumers because they are well known and represent a high standard in green management [49]. During hotel reconstruction and redesign, CPI Hotels, one of the largest hotel groups in Czechia not only takes into account the comfort of hotel guests, who can use the latest technologies for their comfort in hotels, but they also actively think about their environmentally friendly operation. The company's goal is to comply with client requirements during the modernization, but at the same time actively participate in environmental protection. Environmental thinking is important, which is why CPI Hotels systematically addresses the issue of reducing the environmental impact of our hotels. "Packaging-free" cleaning agents or more economical LED lights are used in the portfolio of hotels. Paper printouts, napkins, and toilet paper are all made of recyclable material, and entrance cards are made of wood instead of plastic. Guests have the opportunity to sort waste in their rooms and reducing food waste will be resolved by composters. There will be reserved parking spaces and charging stations for electric cars in the hotel. The preferences of today's clients lie not only in high quality, interesting design, and an environmentally responsible approach, but also in greater self-service through modern technologies [50]. 
Independent hotels have not been the focus of most sustainable development goals-related initiatives. In our opinion, the collective efforts of smaller scale and independent hotels, which in several geographical contexts represent the majority of hotels and restaurants, are no less significant. Small and middle-sized accommodation facilities need to overcome the lack of industry know-how to address sustainable development. This, alongside the development of strategic partnerships with local associations and industry groups and the offering of practical, down-to-earth sustainable initiatives, allows small and middle-sized hotels to effectively engage in SDG (sustainable development goals) implementation [5].

As we mentioned in the introduction to the article, a substantial reason for all these initiatives is also the guests. Some of them generally appreciate the practices of eco-friendly hotels by showing a willingness to pay more and sacrifice part of their comfort and luxury during the implementation of environmental measures. Although their demand for eco-friendly accommodation is still relatively low, some guests are looking for hotels that demonstrate the use of environmental practices [51].

Towel reuse is often cited as the number 1 environmental practice in hotels. From a practical point of view, the policy of reusing towels is one of the most effective and widely used practices in the area of environmentally friendly hotels. More than half of guests (53\%) were willing to financially support eco-friendly hotels. The research was conducted in 1304 Greek and foreign guests in Greece [52]. In general, we can say that the willingness of hotel guests to pay for social or environmental well-being keeps growing [3]. Almost three quarters of guests (72\%) would accept the reuse of towels, while $44 \%$ were willing to pay an average of $€ 2.15$ per day to support it. Younger guests who booked hotels with higher prices or longer stays were willing to pay extra for towel reuse programs [52]. With the rise of environmental consumption, consumers are also increasingly critical of hotel practices, especially in cases where it is difficult to verify that environmental motives take precedence over cost ones [46]. Therefore, it is important to have a better understanding of the behaviour of guests regarding the use of eco-friendly accommodation, so that marketing and operational strategies that influence the consumer behaviour of tourism participants can be successfully implemented and put into practice [53].

Initiatives in the green management of a hotel include not only technical activities, but also require strategic management. However, many hotels focus only on technical activity. Financial savings are one of the most influential factors that influence the adoption of environmental initiatives [1]. On the other hand, many hotel managers and owners are concerned about short-term profitability. Levy [54] argues that the high costs of innovation make it difficult for management to take environmental action. Low demand from guests is another barrier for hotels to adopt environmental practices, especially in the Asian context [55]. Some small and middle-sized enterprises (SMEs) suggest that their hotel guests are not concerned about how green their stays are. Given that perspective, it is an unsurprising fact that some organizations feel it is unnecessary to communicate sustainability practices [9]. For example, tourists did not consider staying in an eco-friendly hotel, despite their positive approach to the environment [1], while others believed that staying in eco-friendly hotels was more expensive than staying in regular accommodation [56]. The lack of government regulations on green management within hotels is another obstacle [32]. On top of that, managers' perception and awareness of environmental protection can influence the implementation of environmental initiatives, as it is managers who interpret environmental issues as opportunities or threats and make choices to address these issues $[1,57]$. We state that hotel managers ought to socialize the introduction of new sustainability measures, using the importance of norms, creating peer-systems to learn from each other, and ensuring that the hotel's implementation aspects do not belong to one person only [58].

\section{Materials and Methods}

The aim of this paper is to analyse the application of environmental measures in a selected hotel in Czechia. In connection with the research goal, the following research question was posed: What environmental management measures are applied in the selected hotel? In this paper, primary data collected by structured and semi-structured interviews with TOP management and by author 
observation were used. A total of 8 interviews were conducted (Front Office Manager, Food \& Beverage Manager, Facility Manager, and Executive Housekeeper). The first interviews lasted approximately 20-25 min; the second interviews lasted 10-15 min. The first round of interviews examined the attitudes of TOP management to eco-measures and examined what measures were used in individual sections. The second round followed the observations, and the aim was to provide feedback on the implementation of environmental measures for TOP management and discussions on control mechanisms. Author observation was conducted from April 2017 to March 2018.

We believe that this period is long enough for us to be able to find out how the hotel operates, how environmental measures are enforced, and whether they are put into effect by employees. During the research, it was possible to observe the system and work procedures that are in operation in the hotel.

This paper presents a pilot study whose purpose is to determine the extent of data and information used for green management tools that can be obtained by the method of structured interviews and observations in the hotel. The findings and procedures with evident informative value will be used in extended research at other accommodation facilities in the region and subsequently in Czechia. The intention is to verify the propositions in the future:

- The presentation of the accommodation facility as eco-friendly has demonstrably increased its visitor rate.

- The introduction of environmental measures has affected the visitor composition when compared to previous seasons.

- The use of environmental measures has reduced building operating costs (water and electricity).

A total of 28 environmental measures were examined in 6 areas (Table 4).

For the evaluation we used the analysis method (also Correspondence analysis-CA), mathematical, and statistical methods. Using the graphic tools of this CA, it is possible to describe an association of nominal or ordinal variables and to obtain a graphic representation of a relationship in multidimensional space-for the readers; it is easier to understand. The analysis provides further evidence that correlations exist between variables.

Correspondence analysis (CA) is a multivariate statistical technique. It is conceptually similar to principal component analysis but applies to categorical rather than continuous data. In a similar manner to principal component analysis, it provides a means of displaying or summarizing a set of data in a two-dimensional graphical form [59].

All data should be non-negative and on the same scale for CA to be applicable, and the method treats rows and columns equivalently. It is traditionally applied to contingency tables. CA decomposes the chi-squared statistic associated with this table into orthogonal factors. The distance between single points is defined as a chi-squared distance. The distance between the $i$-th and $i^{\prime}$-th row is given by the formula

$$
D\left(i, i^{\prime}\right)=\sqrt{\sum_{j=1}^{c} \frac{\left(r_{i j}-r_{i^{\prime} j}\right)^{2}}{c_{j}}}
$$

where $r_{i j}$ are the elements of row profiles matrix $\mathrm{R}$ and weights $c_{j}$ correspond to the elements of column loadings vector $\mathrm{cT}$, which is equal to the mean column profile (centroid) of the column profiles in multidimensional space. The distance between columns $j$ and $j^{\prime}$ is defined similarly, weights correspond to the elements of the row loadings vector $r$ and sum over all rows. In correspondence analysis we observe the relation between single categories of two categorical variables. The result of this analysis is the correspondence map introducing the axes of the reduced coordinates system, where single categories of both variables are displayed in graphic form. The aim of this analysis is to reduce the multidimensional space of row and column profiles and to save as far as possible original data information. Each row and column of the correspondence table can be displayed in c-dimensional (r-dimensional respectively) space with coordinates equal to the values of the corresponding profiles. 
The row and column coordinates on each axis are scaled to have inertias equal to the principal inertia along that axis: these are the principal row and column coordinates [60].

Table 4. Surveyed environmental measures.

\begin{tabular}{|c|c|}
\hline Elements & Measures \\
\hline economic and social activities & $\begin{array}{l}\text { - } \quad \text { purchasing commodities and products within the region, } \\
\text { - } \text { supporting local infrastructure, } \\
\text { - utilizing public transport and bikes, } \\
\text { - employing locals }\end{array}$ \\
\hline $\begin{array}{c}\text { communication and raising employees' } \\
\text { and guests' awareness }\end{array}$ & $\begin{array}{l}\text { - } \quad \text { steady plan for staff training in working with } \\
\text { new technologies, } \\
\text { - } \quad \text { setting work procedures and checking their implementation, } \\
\text { - promoting a public environmental program, } \\
\text { promoting the observance of environmental principles } \\
\text { by guests, }\end{array}$ \\
\hline management & $\begin{array}{l}\text { - } \quad \text { implementing EMAS, EN ISO } 14001 \text { standards, } \\
\text { - } \quad \text { purchasing in bulk, } \\
\text { - } \quad \text { giving priority to "eco-friendly" products, } \\
\text { - } \quad \text { purchasing quality and truly needed products, } \\
\text { - } \quad \text { purchasing products from regional suppliers, }\end{array}$ \\
\hline waste management & $\begin{array}{l}\text { - } \quad \text { sorting waste at the hotel, } \\
\text { - } \quad \text { recycling bins for plastic, paper, etc. in hotel rooms, } \\
\text { - } \quad \text { multiple reuse of recyclable materials, } \\
\text { - composting organic waste, etc. }\end{array}$ \\
\hline energy conservation & $\begin{array}{l}\text { - } \quad \text { geothermal energy and waste heat utilization, } \\
\text { - } \quad \text { heating and air-conditioning control, } \\
\text { - } \quad \text { energy efficient appliances and technologies, } \\
\text { - thermal insulation of buildings, }\end{array}$ \\
\hline water conservation & $\begin{array}{l}\text { - installing single lever taps and faucet aerators, } \\
\text { - } \quad \text { installing water-saving shower heads, } \\
\text { - } \quad \text { dual-flush toilets, } \\
\text { - } \quad \text { rilizing grey water, } \\
\text { - } \quad \text { replacement of bed linen and towels upon request. }\end{array}$ \\
\hline
\end{tabular}

Source: Authors' own elaboration.

For the correspondence analysis model, the degree of dispersion of points is defined, i.e., row and column categories, the so-called total inertia. The term inertia comes from mechanics, where it is defined as the sum of the product of mass and square distances from the centroid of all the object's particles. Geometrically, inertia expresses the degree of dispersion of points in multidimensional space and it can be understood as an analogy to the dispersion known from statistical modelling. In a correspondence analysis, the total inertia $(I)$ is equal to the weighted average (with weights $p_{i+}$ ) chi-square of the distance of the row profiles from their average/mean (vector $c$ ) [60,61],

$$
I=\sum_{i=1}^{r} p_{i+}\left(r_{i}-c\right)^{T} D_{c}^{-1}\left(r_{i}-c\right)
$$


The same as the weighted average (with weights $p_{+j}$ ) chi-square of the distance of the column profiles from their average (vector $r$ )

$$
I=\sum_{j=1}^{c} p_{+j}\left(c_{j}-r\right){ }^{T} D_{r}^{-1}\left(c_{j}-c\right)
$$

A significant part of the total inertia of the original table is usually explained by the first several axes. That is why it is generally sufficient for the result of the correspondence analysis to be represented in the space of the first two or three ordinal axes. Total inertia equals the sum of all eigenvalues of the matrix. Therefore, it is possible to specify how many ordinal axes it is reasonable to interpret. This can be decided in either of two ways. (1) We set a threshold value (e.g., 80\%) and determine how many axes have a cumulative inertia higher than the set threshold value. (2) We interpret the ordinal axes whose eigenvalue is above-average, i.e., higher than the average of all eigenvalues $[60,61]$.

The contributions of the row points to the inertia in the corresponding dimension are defined by the quotient

$$
\frac{r_{i} f^{2} i k}{\lambda_{(k)}}
$$

where $\int_{i k}$ corresponds with the elements of the matrix $\mathrm{F}$ (the score of the $i$-th row category in the $k$-th dimension), $r_{i}$ elements of the row loadings vector and $\lambda_{(k)}$ is inertia expressed by the $k$-th dimension (an eigenvalue of the matrix). A contribution of the row points to inertia expresses the relative degree of the effect of the given category on the final orientation of the main axes [60,61].

In a similar fashion, the contributions of column points to inertia are expressed in the corresponding dimension

$$
\frac{c_{j} g^{2} j k}{\lambda_{(k)}}
$$

For each row category, we can calculate the total row inertia, defined as

$$
\sum_{n=1} r_{j} f^{2} j k
$$

Similarly, for column categories, the total column inertia is defined as

$$
\sum_{k} c_{j} g^{2} j k
$$

The values of inertia for individual columns and rows give us an indication of the significance of the various categories on the resulting ordination $[60,61]$.

\section{Results and Discussion}

The examined hotel falls within the Standard class. It is located in the Vysočina Region and with its 22 rooms it ranks among small accommodation facilities. It includes a restaurant, mini-brewery, two conference rooms, sauna, and swimming pool. The hotel does not have an environmental certificate, yet the concept of the hotel is based on environmental principles. The hotel building itself shows a tendency towards the principles of sustainable development. Local building materials were used for the construction and its design corresponds to the local architecture. Of the 28 environmental measures examined, the hotel applied almost all. In the surveyed hotel, greenwashing is not carried out. The following text is focused on their implementation in more detail. All examined measures are voluntary except for waste sorting, which is mandatory by law (Act No 185/2001 Coll., On Waste and Amendment of Some Other Acts), [62]. 


\subsection{Economic and Social Activities}

Purchasing of ingredients and products in the region. An important element of the hotel restaurant was the offer of freshwater fish. The offer includes carp, tench, maraene, grass carp, pike, eel, catfish, silver carp, sander, trout, and the only sea fish on the menu, salmon. Most of the fish came from their own resources or from local suppliers. There were vats with a recirculation system for fish farming situated in the basement of the hotel. Thanks to the facilities for breeding live fish, fish supplies were not so frequent, and the fish were always fresh. On the other hand, the maintenance of these recirculation systems was a great burden in terms of water consumption. Many ingredients and products were not imported from an external source but were produced directly in the hotel kitchen or brewery. These included tartar sauce, whipped cream, pasta, and beer, which received the Regional Food mark. This mark is awarded by the Ministry of Agriculture to the highest quality agricultural and food products in the Vysočina Region. When selecting suitable suppliers, cooperation with local businesses was preferred. Especially with regular deliveries of ingredients to the kitchen, care was taken to select suppliers from nearby. For less frequent deliveries, cooperation with suppliers from more distant places was maintained, but mostly from within the Vysočina Region. Almost one third of suppliers (32\%) were local, another $32 \%$ of suppliers were from more distant places (from 20 to $50 \mathrm{~km}$ ), while $23 \%$ of suppliers were from surrounding places (up to $20 \mathrm{~km}$ ) and $13 \%$ of suppliers were from outside the Vysočina Region.

Support for local infrastructure. The hotel has maintained good relations with the city council and has collaborated with it in some local activities. In 2015, a new lookout tower was built, where an entrance fee was charged. Through free admission for hotel guests, the hotel increased the attendance of this town attraction. The hotel and brewery supported sports events, local balls, a charity for children and young people with disabilities, etc., with their sponsorship gifts. There was also close collaboration between the hotel and the secondary hotel school. Most students were allowed to carry out work experience directly in the hotel kitchen or restaurant. Some students were satisfied with the experience, so they often remained as part-time workers, or even as permanent employees. The hotel staff also regularly maintained the sidewalk and car park in front of the hotel, despite the fact that it was used not only by hotel guests and customers of the brewery, but also by the general public.

Use of public transport and bicycles. There are shortcomings in this area in both employees and hotel guests. Many employees used cars to go to work, even though they lived in the same town as the hotel. Staff from the nearby area also commuted by car, bus, train, or even bicycle. Guests either used their own car or ordered a taxi. Bicycle stands were placed next to the hotel in the car park, but there was not enough space in the interior or in the yard to store bicycles. Other environmentally friendly modes of transport have not been promoted by the hotel.

Employing local people. More than half of the employees (58\%) were local, another $36 \%$ were from the surrounding villages within $10 \mathrm{~km}$, and the rest of the employees were from a distance greater than $10 \mathrm{~km}$. When selecting new employees, the hotel management asked about the place of residence and the mode of transport that the potential employee would use.

\subsection{Communication and Trainings of Employees and Hotel Guests}

Certain cost-saving measures were instilled in new employees during the initial training. All receptionists in charge of most office work were required to conserve office paper and, if possible, use the reverse side of printed paper for notes and messages. The training also focused on more efficient copying. If only part of the paper was printed, the rest was used for notes or further printing. When wastage was spotted, the employee was immediately notified of this deficiency and a remedy was arranged. On the other hand, it should be noted that the inspection was conducted rather randomly.

Kitchen staff were encouraged to conserve water, energy, and food. The training focused on food leftovers management, sorting of organic waste, washing dishes and the correct use of the dishwasher in order to prolong its life and to fully utilize its capacity. If the chef or another manager observed that these measures had not been complied with by the employees, a strict warning followed so that 
similar wastage would not be repeated in the future. A regular daily inspection took place in this area. All employees were also informed about how to close windows and doors correctly when the heating or air conditioning is on to avoid unnecessary energy waste. If a fault was discovered, employees were immediately alerted to rectify the situation and also explained the financial and environmental consequences of these deficiencies.

Insufficient training and checks of employees can be observed in the areas of waste sorting, water management, and switching lights on and off. Many activities thus depended only on the awareness of employees and their willingness to take cost-saving measures.

Environmental measures were also instilled in hotel guests. In each room's bathroom there was a multilingual information sign about the environmental towel-washing program. However, when it comes to other cost-saving measures, the guests were insufficiently informed. There was no promotion of environmental modes of transport, no incentives to conserve water or energy, nor encouragement to sort waste.

\subsection{Management}

Implementation of ISO 14001 and EMAS (Eco-Management and Audit Scheme) environmental systems. None of these environmental management systems was employed in the hotel. The leading employees of the individual departments knew about these systems, but only marginally, and their introduction in the near future was not considered. Investments in these systems were not found to be sufficiently efficient.

Minimization of packaging. Detergents were not bought in small bottles, but in larger barrels, from which they were poured into smaller, reusable bottles. In this way, maids' cleaners, soaps in toilets, laundry detergents, cleaning products at the reception, dish detergents in the kitchen, shower gels in guests' bathrooms, etc., were refilled. A system of returnable packaging or boxes was also was put in place. The supplier delivered the raw materials in new packaging and subsequently took back the packaging from the previous delivery. This resulted in a cycle of repeated use of containers and packaging without unnecessary production of waste. This system worked with suppliers of bakery products, vegetables, desserts, homemade syrups, and other food.

Purchasing of products needed by the hotel. Purchasing of ingredients for the kitchen was planned according to the expected consumption. There was a clear tendency in the kitchen supply system to buy only those ingredients that were subsequently sold, so that no unnecessary waste was created. Breakfast ingredients (eggs, bakery products, smoked meat products) were ordered according to hotel bookings. If there was a larger booking in the hotel restaurant, guests were required to send a selection of dishes in advance and a food order for the kitchen could be planned accordingly.

There were e-mail and telephone advertising offers sent to the hotel, which were focused on accommodation and catering facilities. Most often, these were offers of hotel furniture, bed linen, cleaning products, and banquet table skirts or dishes. All these offers were handed over to the head of operations, who verified and considered the offers. In most cases, the offers were not responded to, as the products were already in the hotel and did not need to be replaced. In case of less frequent use, it was easier to rent them from an external source. The hotel management prevented unnecessary purchases and subsequent non-use of the ordered goods. In the case of goods that were really needed for the hotel and where it was not worth renting them, a meeting of the hotel management was held during which the purchase of these goods was considered. The necessity of the given product, its quality, reliability, and distance of the supplier were assessed. For small goods, much power was left to employees in operation. Cleaning aids, maintenance tools, light bulbs and similar items were purchased by cleaning and maintenance staff when they were really needed, and they were subsequently reimbursed for their expenses. This approach really encouraged the purchasing of only the necessary goods which the employees used.

Purchasing of high quality and useful products. In the past, the hotel kitchen and restaurant were equipped with refrigeration equipment and appliances which were not adapted to the operating 
conditions of the hotel kitchen and thus were subject to rapid wear and tear and required frequent repairs. At present, the kitchen and restaurant are equipped with quality equipment designed for hotel kitchens from a company named In gastro. These devices do not have such frequent failures and their service life is longer. Besides the equipment for long-term use, attention was also paid to consumer goods. The hotel collaborated with smaller businesses that focused on home and handmade production. For example, high-quality homemade syrups with a large proportion of fruit, originating from a small production of a small tradesman, were used for the offer of soft drinks. In addition, these syrups were supplied in larger glass bottles, which were returned to the supplier after the contents had been used up. The hotel restaurant also offered homemade desserts from a local businesswoman. They were also delivered in glass or ceramic forms, which were returned to the supplier for reuse. Other products sold at the hotel were blow-moulded beer mugs from a small glassworks located in the village of Bohdalov near Velké Meziříćí, high-quality chocolates of the Lyra brand, Hustopečská Mandlovice (almond brandy from Hustopeče), Moravian wines from the Buček family winery, hops for the beer production from the Hop Company, and other products. Many products offered in the hotel restaurant hold the Regional Food of the Vysočina Region mark. These include, e.g., Lacrum cheeses, pate from Bíteš called Sláma, or Excelsior cake.

Supply of "eco" products. Many of the products delivered to the hotel hold various environmental certificates. One of these products is the Alpa chemist's, whose products have received the EKO-KOM and Envipak certificates. Winterhalter dishwasher detergents even hold the EU Ecolabel certification. Other environmentally friendly products include Ecolab Hygiene detergents, HP printers and scanners focused on environmental sustainability, some organic food, and more.

\subsection{Waste Management}

Proper waste management. There were containers for plastic, paper, clear and coloured glass, and municipal waste located behind the hotel. There were also large bins for spent grains in the courtyard of the hotel. In all toilets and bathrooms, there were waste bins intended for hygienic needs which were not allowed to be flushed down the toilet. The discharge of hazardous substances into the sewer was also prevented. The waste drains were not cleaned chemically, but manually using a plunger or another, more gentle method. Significant sums have been invested in the hotel for the removal and export of kitchen waste using the Lapol system. Thanks to that, no fats or food residues were discharged into the sewer. On the other hand, the waste management of the hotel has one major drawback. There were no separate bins for basic waste sorting in the hotel rooms or anywhere else. All sorting was left to the employees, who ordinarily sort clean plastics, cardboard, and glass. Contaminated plastics and most of the paper waste are disposed of in municipal waste. Within one week, the hotel produced approximately $1820 \mathrm{dm}^{3}$ (one container with a volume of $1100 \mathrm{dm}^{3}$ and three bins with a volume of $240 \mathrm{dm}^{3}$ ) of municipal waste, $1100 \mathrm{dm}^{3}$ (one container) of paper waste, $220 \mathrm{dm}^{3}$ (one fifth of a container) of plastics, and $550 \mathrm{dm}^{3}$ (one half container) of glass. The smallest was the volume of plastic waste; this was not due to low consumption of plastic packaging and products, but due to insufficient sorting of plastics. The largest volume of waste was municipal waste, which included unsorted paper and plastics. An essential prerequisite for waste sorting is the placement of separate bins for plastics, paper, and other waste in hotel rooms and other places such as receptions, restaurants, kitchens, and congress halls. The implementation of this measure is not costly, but it requires enough space to be reserved, which is not an easy task, for instance, at the reception or in the restaurant. Reuse of recycled materials. The hotel had a system for the reuse of paper, i.e., printed spreadsheets, tables, or invoices that were no longer needed or that had printing errors were cut into smaller pieces and their clean reverse side was used for messages and short notes. Cost-saving measures in the field of waste also included the replacement of used cartridges with new ones, and the replacement of old light bulbs with new ones. Reusable ceramic or glass dishes were used instead of disposable packaging for some food. Instead of disposable packages of cosmetics and soaps for hotel guests, larger packages of shower gels were used and refilled. Recycled soft toilet 
paper was available in the rooms. The hotel guests' requirements are also often at odds with the cost-saving measures applied in the hotel. Removal of disposable cosmetics from rooms, replacement of single-serving food packages, or less frequent linen changes are perceived negatively due to guests' low awareness.

Food handling. A large amount of organic waste was produced in the hotel kitchen. Most of the food leftovers were sorted and reused. A minimum of food was disposed of in municipal waste. All the remaining bread was used to make croutons for soup, to feed the fish or was handed over to a local poultry farmer; plant-based food leftovers were handed over to a pig farmer and the spent grains were used as cattle feed. In this way, the hotel saved food, reduced waste, and supported local farmers. The main shortcomings in the area of waste included the use of single-serving packs of sugar, butter, jam, chocolate spread, and cheese. A large quantity of packs was produced in this way. Another shortcoming was the use of disposable plastic straws, the sale of plastic bottles for beer, non-returnable glass bottles and non-returnable small beer kegs. Only for barrels with a volume of 15 litres and more was the system of return against a deposit used, thanks to which the packaging was reused, and no additional waste was generated. A large amount of non-recyclable waste also came from the use of paper hand towels in the toilets.

\subsection{Power Savings}

Use of geothermal energy. There was a heat pump originally built in the hotel. However, due to the layout of the building and the high maintenance costs, this method was not found to be the most economically advantageous by the hotel management. At present, the hotel uses gas heating, which allegedly requires similar monthly costs as pump heating, but ongoing repairs and maintenance are cheaper. Heating with a pump is more environmentally friendly, but even gas heating does not leave such an impact on the environment as solid fuel heating or electric heating.

Heating and air conditioning regulation. In all hotel rooms, conference rooms, and at the pool, the heating was set using a central temperature control system. Instructions for temperature changes were given from the hotel reception by trained staff. The guests could not control the temperature in their room themselves but were informed in the hotel rules about the possibility of raising or lowering the temperature on request. The heating in the room was switched on during the guest's registration. When the room was unoccupied, the heating was switched off; the temperature in the occupied room was maintained at $22^{\circ} \mathrm{C}$ during the day and at $19{ }^{\circ} \mathrm{C}$ during the night. In the peripheral rooms, which were more susceptible to weather changes, the temperature setting was adapted to the current temperature. Air conditioning was used only in the lecture halls, at the reception and in four guest rooms. In this case, guests could set the temperature themselves. The installed air conditioners were economical. When cooling, they fell into the A+ category and when heating, they fell into the A category.

Use of energy saving light bulbs. The hotel used several types of lighting, from the most economical LED bulbs to conventional bulbs. The most economical LED lighting was most often used. The most often represented bulbs were LED Candles, which resembled a candle, and which aesthetically fit into the period interior of the hotel. Older, less energy-saving light bulbs have been replaced with newer, more energy-saving ones. In certain places, such as less frequented corridors, some toilets, or the courtyard and the entrance to the courtyard, motion-sensor lights were used (Table 5). 
Table 5. Type of lighting.

\begin{tabular}{cccc}
\hline Type of Lighting & $\begin{array}{c}\text { Input Power Corresponding Input } \\
\text { Power of a Classic Light Bulb (W) }\end{array}$ & Class & Savings \\
\hline LED Candle & $6 / 35$ & $\mathrm{~A}+$ & 85 \\
LED Classic & $6 / 40$ & $\mathrm{~A}+$ & 85 \\
LED Gu10 & $6.3 / 46$ & $\mathrm{~A}+$ & 86 \\
Ecolite LED & $7 / 50$ & $\mathrm{~A}+$ & 86 \\
Nedes & $12 / 85$ & $\mathrm{~A}+$ & 85 \\
LED A60 & $12.5 / 120$ & $\mathrm{~A}++$ & 90 \\
NBB Bohemia Super & $13 / 56$ & $\mathrm{~A}$ & 77 \\
Compact & $16 / 80$ & $\mathrm{~A}$ & 80 \\
Fulgur 2D & $20 / 110$ & $\mathrm{~A}$ & 82 \\
NBB Bohemia Infinite & $50 / 50$ & $\mathrm{D}$ & 0 \\
Gu10 Eyarn D & $50 / 50$ & $\mathrm{D}$ & 0 \\
\hline
\end{tabular}

Source: Authors' own elaboration.

Energy-efficient appliances and low-energy technologies. Most of the kitchen equipment, refrigerators, freezers, and cooking equipment came from In Gastro, which focuses on modern and highly durable appliances for hotels and restaurants. All these devices allow change of the temperature and increase or decrease of their power consumption. A special economy mode can be used with Winterhalter dishwashers, which wash dishes in a short time at relatively low temperatures. Refrigerators for beverages with a daily consumption of $2.50 \mathrm{kWh}$, which did not correspond to any economy class, were located at the reception and the same problem occurred in the restaurant with refrigerated beverage boxes. Technology to reduce heat consumption was in operation at the hotel pool. There was a cover installed on the pool, which was open only when the pool was occupied. This cover prevented not only pollution falling into the pool, but also heat escaping from the water.

Thermal insulation of the building. All the windows were replaced during the reconstruction in 2003. Insulating windows with double glazing were used, preventing heat escaping and helping to conserve energy. Although more energy-efficient windows are already being produced, the existing ones still perform their function satisfactorily and do not let heat escape. The door to the hotel was more worn due to more frequent use and did not seal very well. There were relatively significant heat escapes through the door. The building is completely insulated. Due to the preservation of the original stucco decoration, it was not possible to insulate the building from the outside, so it was insulated from the inside.

\subsection{Water Savings}

Installation of single lever taps and aerators. There were only single lever taps in the hotel rooms, in the kitchen, in the restaurant, and in the lecture halls, enabling quick temperature setting and easy start or stop of the water flow. This prevented unnecessary leakage. Aerators were placed in the water taps and showers, creating the impression of a stronger stream. In general, however, less water is used in the shower than in the bathtub. More than two thirds of the hotel rooms $(68 \%)$ had a shower and bathtubs were installed in the remaining rooms.

Installation of two-stage flushing. All toilets in the hotel are equipped with a two-stage flush, while the smaller one flushes with three litres of water and the larger one with seven litres of water. In the event of a detected defect, such as a leaking toilet, the hotel manager was immediately informed, and an immediate repair was carried out to avoid unnecessary losses.

Washing and dishwashing. Washing machines and dishwashers were switched on only when there was enough laundry or dishes. The environmental program for washing of towels and bed linen prevented frequent washing and frequent discharge of detergents into wastewater. In the case of longer stays of hotel guests, towels were changed on request and bed linen was changed once or twice a week at the most. 
Use of rainwater. The hotel did not have a rainwater collection system. However, water from an outdoor river raceway, which originally led to the mill, was used for fish farming. This water flowed into the recirculation systems, then was cleaned of all nitrates and other harmful substances, and then fed back to the external raceway, where it became part of the natural cycle. Thanks to this measure, fish farming was not such a burden in terms of water consumption or the environment.

\subsection{Recommendations}

There were many environmental measures employed in the hotel which worked well. On the other hand, there were areas where elements of environmental management were neglected without major tendencies to remedy this. At the same time, some measures were not difficult or too costly to implement. The following measures were recommended and are arranged from the least demanding to the most difficult to implement.

The CA method was used to better illustrate these recommendations. This method describes an association of nominal or ordinal variables to obtain a graphic representation of a relationship in multidimensional space. On the one hand, the variables are hotel, restaurant, and brewery (blue circle), and on the other, there are individual recommendations (red square). The closer the individual recommendations are to the operational part, the more the hotel's TOP management prefers those to other recommendations. Hotel recommendations are all on the same level (LED bulbs, separate bins, more effective training, ... ). It is impossible to determine which recommendation is more important for the hotel and will be implemented more quickly in practice. In reality, the hotel must decide which recommendations are most cost-effective. In the case of the restaurant, the recommendations regarding returning all boxes to suppliers seem to be the most important. As a recommendation for the brewery, CA results in reducing plastic consumption (Figure 1).

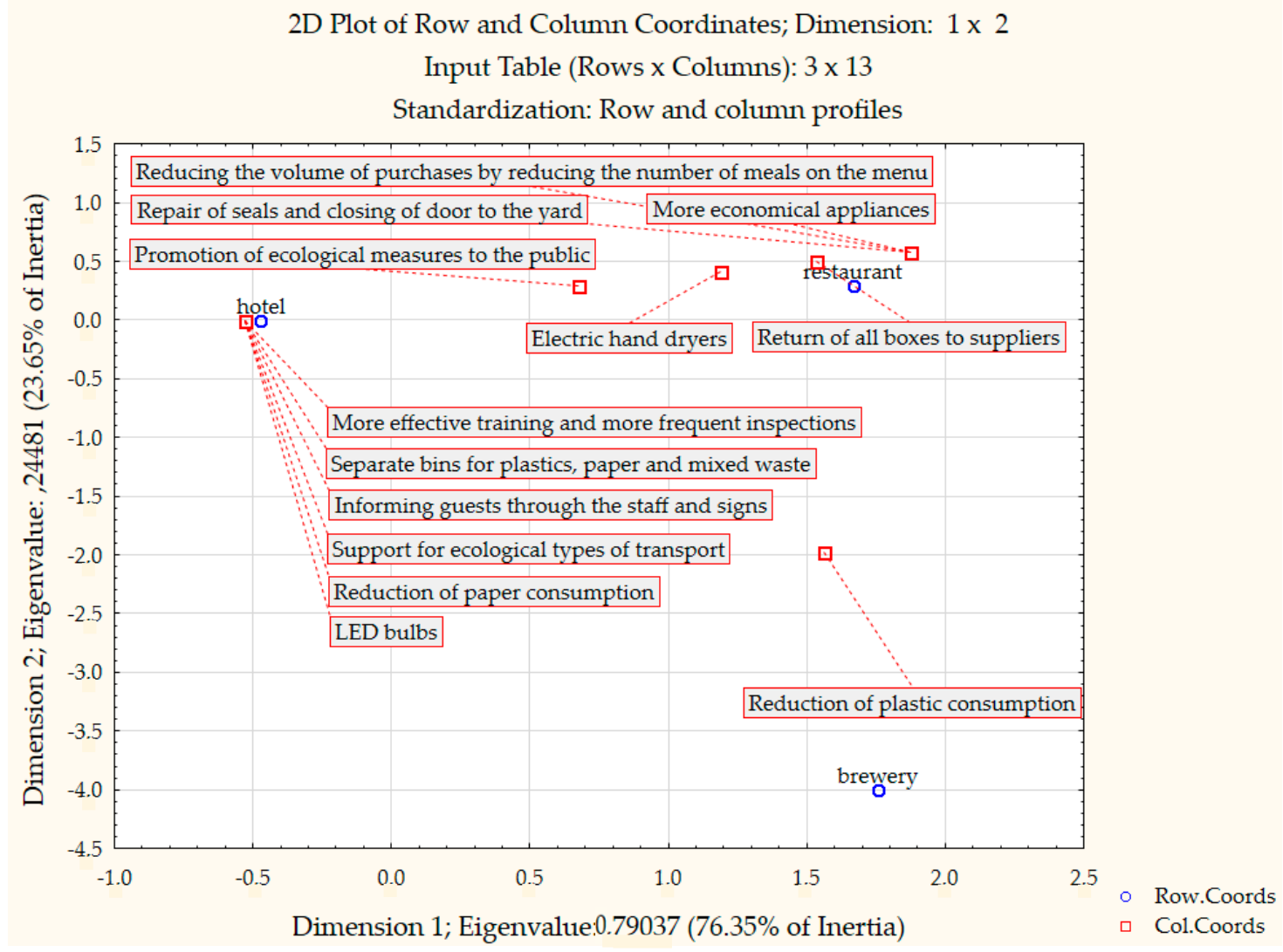

Figure 1. Individual recommendations. Source: Authors' own elaboration.

These recommendations were discussed with TOP management. 
Place separate baskets for plastics, paper, and mixed waste at least on each corridor and in both conference rooms. There was enough space in these areas and waste sorting would be greatly simplified by this measure. At the reception, it was recommended to introduce at least the sorting of mixed waste and paper, although there was not enough space. For example, replacing the existing large mixed waste bin with a smaller bin would create space for a box for papers. This would significantly reduce the amount of municipal waste produced and the hotel would save the removal of at least one municipal waste bin $\left(240 \mathrm{dm}^{3} /\right.$ week).

Reduction of paper consumption, for example, by setting up an electronic messaging document instead of paper messages. It would also be possible to avoid unnecessary printing of proofs of payment that guests did not require. The paper consumption could also be reduced by using envelopes less often. In addition to postal purposes, envelopes were used to store cash in the safe, for gift vouchers and for meal vouchers. They were often used just once. If the envelope is used repeatedly or in some cases not at all, the proportion of waste generated by the paper would decrease.

Repair of seals and closing of the door to the yard, which cannot be completely closed and allows heat to escape the whole day. This door was used very frequently, because it served as the main passage to the second accommodation building, but also to the storerooms used by the chefs, waiters, and receptionists. The door was thus considerably worn and did not fit tightly. However, this was also related to the correct closing of this door, which should be taught to both guests and employees.

Reduction of plastic consumption, especially in the conference rooms, where the highest consumption of plastic packaging took place. The main reason was the fact that plastic bottles of mineral water with a volume of 0.51 were available to the participants. The proposal was to replace the bottles with larger packages or to offer an alternative-preparing a jug with filtered tap water from the restaurant.

In the conference rooms, it was also possible to fill glasses with tap water. This method should be promoted more in the participants of the training than the offer of bottled water. Other proposals included reduction of the production of beer in plastic bottles, re-use of plastic garbage bags, reduction in the sale of plastic bags, and reducing the use of plastic straws in beverages.

Replacement of the remaining classic light bulbs and energy-saving fluorescent lamps with an LED variant. The most energy-saving LED lamps have already been installed in the majority of the lighting fixtures, but there is still room for improvement. As LED bulbs are up to $80 \%$ more economical and have a much longer life, energy consumption and waste production would be reduced.

Returning all boxes to suppliers. Suppliers of juices, sandwiches and glasses used paper boxes, which they did not take back. There was no space for storage in the hotel, so they were usually thrown into a paper waste container. Suppliers could pick up and reuse these boxes during the following delivery without constantly producing new ones. It should be noted that this system worked for most suppliers.

Reduction of the volume of purchases by reducing the number of meals on the menu. Although the orders were planned according to the expected sales, it was necessary to store many ingredients in stock. The supplies required storage facilities and the operation of refrigerators and freezers, which brought energy consumption. The main reason was the wide range of meals. For example, salads from the salad bar in the restaurant allowed a rich selection of ingredients according to the guests' wishes. On the other hand, many ingredients from this box were not consumed and were discarded. If the offer of salads from the bar was replaced with a limited offer of salads to order, there would be no waste of food and the operation of one whole cooling device would be saved. By omitting some other stored ingredients, it would be possible to reduce the number of refrigeration units in the kitchen storerooms and in the restaurant.

Reduction of the energy consumption of air-conditioning units by installing sun protection film on glass surfaces. In the summer months, the rooms are overheated by sunlight, and as a result, the energy consumption of the air-conditioning units increases. The largest consumption took place in the attic conference rooms with skylights. This could be prevented by installing sun protection film on the 
window glass. Such film stops $99 \%$ of harmful UV radiation, reducing the room temperature and also protecting the interior equipment from premature aging.

Reduction of heating energy consumption using thermal insulation foil. Heat losses are caused by heat escaping through glass surfaces. The windows of the hotel were equipped with double glazing. Replacement with new triple-glazed windows would require hundreds of thousands of Crowns in investments, so it was recommended to install thermal insulation foils the purchase price of which is significantly lower and whose properties correspond to triple-glazed windows.

Replacement of disposable paper hand towels with electric hand dryers. This measure would reduce the amount of non-processable waste in the form of used paper towels. However, some electric dryers are a significant burden on energy consumption, so it was recommended to choose the most economical variant of this device. For example, EcoStep hand dryers (price approx. € 1200) state energy savings of up to $90 \%$ and are ISO 14001.

More economical appliances. When replacing appliances, it is also necessary to choose the most economical variant, preferably A ++ or A +++. Many appliances in the hotel were relatively new, so it was recommended to replace only those at the end of their service life. Such replacement could take place in the coming years for refrigerators at the reception, refrigerators for drinks in lecture halls, refrigerated boxes in the restaurant, minibars in the rooms, vacuum cleaners, and other appliances.

More effective training and more frequent inspections. The opportunity for improvement was found during training in the RcWare system used for setting temperatures. Employees should know how to adapt the temperatures to the weather and other external conditions. Almost no training or inspections took place in the area of switching the lights on and off and in the correct dosing of cleaning agents. In many areas, the training took place without explaining the reasons for some of the measures. The training should also include information about the results. If, for example, a reduction in the amount of waste produced or lower energy and water consumption has been achieved, employees should be made aware of these facts and rewarded in some way.

Informing guests through the staff and signs. Guests should be advised to conserve water during normal hygiene and by using the two-stage flushing and instructed not to throw anything but toilet paper into the toilets. In addition, guests should be aware of the need to sort waste and avoid opening the windows with the air conditioning or heating on. This information should be provided by the receptionist upon arrival. In most cases, however, there was not enough space in such a short time to transmit so much information. It is also possible to place multilingual signs informing about individual recommendations, similar to those notifying of the environmental towel washing program.

Promotion of environmental measures to the public. The hotel should provide information on its environmental efforts on its website and in information leaflets. An explanation of the use of larger shower gel packs instead of disposable products as well as the system of towel washing, and linen changing could be posted in the hotel and accommodation section of the website. This would avoid any misunderstanding of these measures and spread awareness of how to be environmentally friendly. It should also be further promoted that supplying the hotel with products from local suppliers has a positive environmental impact.

Support for environmental types of transport. The town has many bike trails and attractions, accessible on foot or by bike. It was recommended to inform the guests about these possibilities on the website or in person and to prepare at least minor facilities for safer storage of bicycles, e.g., in the back part of the yard.

Education of managers in the field of environmental management. Managers should attend a seminar focused on environmental operation or learn about industry trends through professional publications. If they do, it will be easier to find ways to run the hotel more efficiently with lower costs and lesser impact on the environment. On top of that, it is easier for managers who have a good understanding of environmental management issues to motivate employees to participate in this program as well. A visit to a hotel that is environmentally friendly could also help and managers could be inspired by how the individual measures are applied there. 
Implementation of an environmental management system, e.g., according to the ISO 14001 or EMAS standards. The implementation of these systems would make the hotel focus more on environmental protection and help create a comprehensive approach to the application of environmental management. The advantage of these systems is the reduction of total costs and the reduction of charges for environmental pollution.

Small and middle-sized hotels are mainly independent accommodation facilities (not hotel chains). In an independently owned hotel, the manager or owner generally enjoys considerable freedom to operate his or her facility. As a result, the extent to which the property is sensitive to environmental concerns depends on the operator's knowledge, attitude, and willingness to act. Conversely, the environmental policies and initiatives implemented by chain-affiliated hotels are developed at the corporate level and maintained across the entire chain [63].

Fourteen years ago, an explosive launch was predicted for the Czech hotel market, which would be characterized by a friendly approach to environmental protection. It was the time when the first eco-friendly hotel in Czechia was officially certified. The number of hotels certified in this way increased to twelve accommodation facilities in two years from then, but the hotels left the association for various reasons in the following years, until only five of them remained in 2020.

If we focus on some selected European countries, we can see in several countries between the years 2007-2014 a significant increase in the accommodation facilities which have the environmental certificate of the European Union, The Flower. Unfortunately, more recent data are not available. We note that in 2007, there is the biggest number of the eco-friendly accommodation facilities in Italy (25), Ireland (11), Austria (seven), Switzerland (six), Netherlands (six), and Denmark (five). It is remarkable that countries that are more environmentally friendly have a minimum of these eco-friendly accommodation facilities: Germany (two), Finland (zero), Sweden (zero), and Norway (zero). Comparing the countries in 2014, it is still Italy in the first place, which increased the number of eco-friendly accommodation facilities by almost 100 accommodation facilities, i.e., an increase of $496 \%$. The most striking development was recorded by France with 104 environmentally friendly accommodation facilities. Compared to 2007, there were only two eco-friendly accommodation facilities; it means the increase of $5200 \%$. Switzerland recorded the increase of $617 \%$ (37), Spain the increase of 500\% (15), Czechia increased by 300\% (six) and Austria by $243 \%$ (17), [64].

We also noticed some declines e.g., Ireland and Denmark. Norway, which is considered as a leader in connection of ecology, there is no accommodation facility certified by The European Union. But we must state that, there are only collected accommodation facilities with a European Ecolabel. Therefore, e.g., countries of the Scandinavian Peninsula of northern Europe did not reach better results. We assume that these countries have a national certificate for accommodation facilities with an eco-friendly approach to the environment. In Norway, Sweden and Finland, the measures for supporting the environment are basically implemented automatically and it is not necessary to own an environmental certificate. Several accommodation facilities in Czechia are in line with this philosophy. They use some measures and elements of the green management but do not own a certificate due to its high financial expenses. In the countries of the Western and Northern Europe, the guests are different, because they are interested and seek eco-friendly accommodation facilities, whereas for Czech guests the most decisive factor is predominately the price [17].

The use of environmental elements and measures can trigger a synergistic effect. There is a presumption that if a guest gets acquainted with the given philosophy of the accommodation facility and learns the environmental principles, he or she will follow them in their everyday life. It is a paradox that over three quarters of accommodation facilities in Czechia are not considering an environmental certificate in the future but find certain advantages in the application of elements of environmental management. The reason for this is high fees, and $80 \%$ of hotel managers state that the decisive factor for potential guests is the price of accommodation, not the ownership of an environmental certificate. The development in hotel services shows a certain environmental direction. Some accommodation 
facilities apply and will apply some elements of environmental management in their operation even without the ownership of an environmental certificate [65].

\section{Conclusions and Limitations}

The aim of this article was to analyse the application of environmental measures in the selected hotel in Czechia. In connection with this subject matter and the set goal, we defined the following research question: What environmental management measures are applied in the selected hotel?

There are several measures in place at the selected hotel. Within the economic and social activities, collaboration with suppliers near the hotel and choosing local employees work perfectly. There is room for improvement, for example, in supporting local infrastructure or promoting environmentally friendly types of transport. Training and awareness of staff in cost-saving measures worked relatively well but passing on information to the public and guests was insufficient. The hotel management works effectively in the areas of purchasing high quality and really needed goods and supply management with minimal packaging. However, there was not a great emphasis placed on the introduction of any environmental management system such as ISO 14001 or EMAS. In another area, waste generation, the hotel behaved in an exemplary fashion. It minimized packaging, did not produce large amounts of leftovers, most of the organic waste was used to support local farmers, and large sums were invested in Lapol, a system for capturing fats and kitchen waste. In the area of energy savings, the use of highly energy-saving LED fluorescent lamps is worth mentioning. On the other hand, the energy consumption of kitchen appliances and refrigerators was relatively high and inefficient. In terms of water savings, the hotel used almost all the recommended measures, for example, a two-stage flushing system, installation of aerators and energy-saving shower heads, and it also prevented the discharge of harmful substances into the sewer. The financial complexity of some measures, as well as lack of knowledge, was a major obstacle in the application of elements of environmental management.

This paper deals with the research of the hotel's environmental measures in some respects, but there are several limitations, too. On the other hand, the mentioned limits provide directions for further research.

Firstly, our research cannot be generalized. We were merely interested in a Czech hotel only. We would like to investigate other hotels in the Vysočina Region in Czechia and compare these data with the results of the other Czech regions. We assume that a comparison of other regions and subsequently countries would be desirable. Furthermore, in our future research, we would like to investigate the connection between the implementation of environmental measures and the profitability of the hotel. The other variables for exploration should be between the implementation of environmental measures and guest satisfaction if there is any correlation. Finally, we want to focus on environmental measures individually (e.g., for analysing solid waste practices in a hotel, categories such as paper, cardboard, garden waste, kitchen and food waste, tissues, PET, nylon, plastic, glass, etc.). In our opinions, the results would have a more meaningful value.

Considering the example of the examined hotel, the implementation of environmental measures in the operation of an accommodation facility does not have to be difficult or too expensive. On top of that, there is always room for improvement in many areas.

Author Contributions: Conceptualization, P.S.; methodology, P.S. and I.L.; software, P.S. and I.L.; validation, P.S. and I.L.; formal analysis, P.S. and I.L.; investigation, K.K.; resources, P.S. and I.L.; data curation, K.K.; writing—original draft preparation, P.S. and I.L.; writing—review \& editing, P.S., I.L., and K.K.; visualization, P.S. and I.L.; supervision, P.S.; project administration, P.S. and I.L.; funding acquisition, P.S. and I.L. All authors have read and agreed to the published version of the manuscript.

Funding: This research received no external funding.

Conflicts of Interest: The authors declare no conflict of interest. 


\section{References}

1. Wan, Y.K.P.; Chan, S.H.J.; Huang, H.L.W. Environmental awareness, initiatives and performance in the hotel industry of Macau. Tour. Rev. 2017, 72, 87-103. [CrossRef]

2. Gupta, A.; Satyabhusan, D.; Mishra, A. All that glitters is not green: Creating trustworthy ecofriendly services at green hotels. Tour. Manag. 2019, 70, 155-169. [CrossRef]

3. Rahman, I.; Chen, H.; Reynolds, D. Evidence of green signaling in green hotels. Int. J. Hosp. Manag. 2020, 85, 102444. [CrossRef]

4. Činčalová, S.; Hedija, V. Firm Characteristics and Corporate Social Responsibility: The Case of Czech Transportation and Storage Industry. Sustainability 2020, 12, 1992. [CrossRef]

5. Raub, S.P.; Martin-Rios, C. "Think sustainable, act local”-A stakeholder-filter-model for translating SDGs into sustainability initiatives with local impact. Int. J. Contemp. Hosp. 2019, 31, 2428-2447. [CrossRef]

6. Jones, P.; Hillier, D.; Comfort, D. Sustainability in the global hotel industry. Int. J. Contemp. Hosp. 2014, 26, 5-17. [CrossRef]

7. Hamilton, C. Consumerism, self-creation and prospects for a new ecological consciousness. J. Clean. Prod. 2009, 18, 571-575. [CrossRef]

8. Motavalli, J. A History of Greenwashing: How Dirty Towels Impacted the Green Movement. Daily Finance. Available online: http:/www.dailyfinance.com/2011/02/12/the-history-of-greenwashing-how-dirty-towelsimpacted-the-green/ (accessed on 26 October 2020).

9. Font, X.; Elgammal, I.; Lamond, I. Greenhushing: The deliberate under communicating of sustainability practices by tourism businesses. J. Sustain. Tour. 2017, 25, 1007-1023. [CrossRef]

10. Morozova, G.Y.; Debelaya, I.D. Green Infrastructure as a Factor for Sustainable Development of Khabarovsk. Econ. Reg. 2018, 14, 562-574. [CrossRef]

11. Kalábová, M.; Abrhám, J. Hunting Tourism as a Sector with Great Potential for the Development of Czech Regions. In Proceedings of the 19th International Colloquium on Regional Sciences, Čejkovice, Czech Republic, 15-17 June 2016; Klímová, V., Žítek, V., Eds.; Masaryk University: Brno, Czech Republic, 2016; pp. 1073-1079.

12. Gössling, S.; Higham, J. The low-carbon imperative: Destination management under urgent climate change. J. Travel Res. 2016, 59. [CrossRef]

13. Belešová, S. Ecological Elements as a Part of Hotels' Social Responsibility. In Proceedings of the Folia Turistica 4, Banská Bystrica, Slovakia, 3-4 April 2014; Gúčik, M., Ed.; Matej Bel University: Banská Bystrica, Slovakia, 2014; pp. 49-54.

14. Pizam, A. Green hotels: A fad, ploy or fact of life? Int. J. Hosp. Manag. 2009, 28, 1. [CrossRef]

15. Park, J.; Kim, H.J.; McCleary, K.W. The Impact of Top Management's Environmental Attitudes on Hotel Companies' Environmental Management. J. Hosp. Tour. Res. 2014, 38, 95-115. [CrossRef]

16. Martin-Rios, C.; Demen-Meier, C.; Gössling, S.; Cornuz, C. Food waste management innovations in the foodservice industry. Waste Manag. 2018, 79, 196-206. [CrossRef] [PubMed]

17. Scholz, P.; Voráček, J. Organizational culture and green management: Innovative way ahead in hotel industry. Meas. Bus. Excell. 2016, 20,41-52. [CrossRef]

18. Martin-Rios, C.; Ciobanu, T. Hospitality innovation strategies: An analysis of success factors and challenges. Tour. Manag. 2019, 70, 218-229. [CrossRef]

19. Ali, Y.; Mustafa, M.; Al-Mashaqbah, S.; Mashal, K.; Mohsen, M. Potential of energy savings in the hotel sector in Jordan. Energy Convers. Manag. 2008, 49, 3391-3397. [CrossRef]

20. Chan, W.W.; Lam, J.C. Energy-saving supporting tourism sustainability: A case study of hotel swimming pool heat pump. J. Sustain. Tour. 2003, 11, 74-83. [CrossRef]

21. Khemiri, A.; Hassairi, M. Development of energy efficiency improvement in the Tunisian hotel sector: A case study. Renew. Energy 2005, 30, 903-911. [CrossRef]

22. Tsai, Y.H.; Wu, C.T.; Wang, T.M. Attitude Towards Green Hotel by Hoteliers and Travel Agency Managers in Taiwan. Asia Pac. J. Tour. Res. 2013, 19, 1091-1109. [CrossRef]

23. Del Río-Rama, M.D.C.; Álvarez-García, J.; Oliveira, C. Environmental Practices. Motivations and Their Influence on the Level of Implementation. Sustainability 2018, 10, 713. [CrossRef]

24. Deng, S.; Burnett, J. Water use in hotels in Hong Kong. Int. J. Hosp. Manag 2002, 21, 57-66. [CrossRef]

25. Gössling, S.; Hall, C.M.; Scott, D. Tourism and Water; Channel View Publications: Bristol, UK, 2015. 
26. Reddy, M.V.; Wilkes, K. Tourism in the Green Economy; Routledge Taylor \& Francis Group: New York, NY, USA, 2015.

27. Bohdanowicz, P. European Hoteliers' Environmental Attitudes: Greening the Business. Cornell Hotel Restaur. Adm. Q. 2005, 46, 188-204. [CrossRef]

28. Bohdanowicz, P. Environmental awareness and initiatives in the Swedish and Polish hotel industries-Survey results. Int. J. Hosp. Manag. 2006, 25, 662-682. [CrossRef]

29. Chan, W.W.; Lam, J.C. Environmental accounting of municipal solid waste originating from rooms and restaurants in the Hong Kong hotel industry. J. Hosp. Tour. Res. 2001, 25, 371-385. [CrossRef]

30. Chen, H.; Hsieh, T. An environmental performance assessment of the hotel industry using an ecological footprint. J. Hosp. Manage. Tourism 2011, 2, 1-11.

31. Hillary, R. Environmental management systems and the smaller enterprise. J. Clean. Prod. 2004, 12, 561-569. [CrossRef]

32. Mensah, I. Environmental management practices among hotels in the greater Accra region. Int. J. Hosp. Manag. 2006, 25, 414-431. [CrossRef]

33. Pham Phu, S.T.; Hoang, M.G.; Fujiwara, T. Analyzing solid waste management practices for the hotel industry. Global J. Environ. Sci. Manage. 2018, 4, 19-30. [CrossRef]

34. Wie, S.H.; Shanklin, C.W. Cost effective disposal methods and assessment of waste generated in foodservice operations. Food Res. Int. 2001, 13, 17-39. [CrossRef]

35. Yi, S.; Li, X.; Jai, T.M. Hotel guests' perception of best green practices: A content analysis of online reviews. Tour. Hosp. Res. 2018, 18, 191-202. [CrossRef]

36. Bansal, P.; Roth, K. Why Companies Go Green: A Model of Ecological Responsiveness. Acad. Manag. J. 2000, 43, 717-736. [CrossRef]

37. Brodsky, S. Help guests go green with energy-management system. Hot. Mot. 2007, 3, 12.

38. International Tourism Partnership. Sustainable Supply Chains. Available online: www.tourismpartnership. org (accessed on 15 November 2020).

39. Filimonau, V.; De Coteau, D.A. Food waste management in hospitality operations: A critical review. Tour. Manag. 2019, 71, 234-245. [CrossRef]

40. Scholz, P.; Linderová, I. Green Management in Accommodation Facilities as a Factor of Regional Development in Vysočina Region. In Proceedings of the 22nd International Colloquium on Regional Sciences, Čejkovice, Czech Republic, 15-17 June 2019; Klímová, V., Žítek, V., Eds.; Masaryk University: Brno, Czech Republic, 2016; pp. 1095-1101.

41. Petkova, E. Environmental practices of hotel businesses. In Proceedings of the International Scientific Conference on Contemporary Tourism-Traditions and Innovations, Sofia, Bulgaria, 19-21 October 2017; Assenova, M., Ed.; Sofia University St. Kliment Ohridski: Sofia, Bulgaria, 2017; pp. 94-108.

42. Kirk, D. Environmental Management for Hotels; Butterworth Heinemann: London, UK, 1996.

43. Henriques, I.Y.; Sadorsky, P. The relationship between environmental commitment and managerial perceptions of stakeholder importance. Acad. Manag. J. 1999, 42, 87-99. [CrossRef]

44. Sharma, S.; Vredenburg, H. Proactive corporate environmental strategy and the development of competitively valuable organizational capabilities. Strateg. Manag. J. 1998, 19, 729-753. [CrossRef]

45. Andersen, O. Industrial ecology and some implications for rural SMEs. Bus. Strategy Environ. 1997, 6, 146-152. [CrossRef]

46. Rahman, I.; Park, J.; Chi, C. G, Consequences of "greenwashing": Consumers' reactions to hotels' green initiatives. Int. J. Contemp. Hosp. 2015, 27, 1054-1081. [CrossRef]

47. Marriott Corporate Responsibility: Environmental \& Green Initiatives. Available online: https://serve360. marriott.com/sustain/ (accessed on 19 October 2020).

48. Leroux, E.; Pupion, P.C. Pierre-Charles. Factors of adoption of eco-labelling in hotel industry. Technol. Forecast Soc. Chang. 2018, 129, 194-209. [CrossRef]

49. Geerts, W. Environmental certification schemes: Hotel managers' views and perceptions. Int. J. Hosp. Manag. 2014, 39, 87-96. [CrossRef]

50. CPI Hotels. Available online: https://www.cpihotels.com/ (accessed on 10 October 2020).

51. Rahman, I.; Reynolds, D. Predicting green hotel behavioral intentions using a theory of environmental commitment and sacrifice for the environment. Int. J. Hosp. Manag. 2016, 52, 107-116. [CrossRef] 
52. Dimara, E.; Manganari, E.; Skuras, D. Don't change my towels please: Factors influencing participation in towel reuse programs. Tour. Manag. 2017, 59, 425-437. [CrossRef]

53. Nimri, R.; Patiar, A.; Kensbock, S. A green step forward: Eliciting consumers' purchasing decisions regarding green hotel accommodation in Australia. J. Hosp. Tour. Manag. 2017, 33, 43-50. [CrossRef]

54. Levy, D.L. Environmental Management as Political Sustainability. Organ. Environ. 1997, 10, $126-147$. [CrossRef]

55. Rahman, I.; Reynolds, D.; Svaren, S. How "green" are North American hotels? An exploration of low-cost adoption practices. Int. J. Hosp. Manag. 2012, 31, 720-727. [CrossRef]

56. Millar, M.; Baloglu, S. Hotel Guests' Preferences for Green Guest Room Attributes. Cornell Hosp. Q. 2011, 52, 302-311. [CrossRef]

57. López-Gamero, M.D.; Molina-Azorin, J.F.; Claver-Cortes. The Relationship between Managers' Environmental Perceptions, Environmental Management and Firm Performance in Spanish Hotels: A Whole Framework. Int. J. Tour. Res. 2011, 13, 141-163. [CrossRef]

58. Garay, L.; Font, X.; Corrons, A. Sustainability-oriented innovation in tourism: An analysis based on the decomposed theory of planned behavior. J. Travel Res. 2019, 58, 622-636. [CrossRef]

59. Zámková, M.; Prokop, M. Comparison of consumer behavior of Slovaks and Czechs in the market of organic products by using correspondence analysis. Acta Univ. Agric. Silvic. Mendel. Brun. 2014, 62, 783-795. [CrossRef]

60. Hebák, P.; Hustopecký, J.; Pecáková, I.; Průša, M.; Řezánková, H.; Svobodová, A.; Vlach, P. Multidimensional Statistical Methods 3; Informatorium: Prague, Czech Republic, 2007.

61. Pérez, J.L. Curso de Estadística. Available online: https://estadisticaorquestainstrumento.wordpress.com (accessed on 15 November 2020).

62. Act No 185/2001 Coll., on Waste and Amendment of Some Other Acts. Available online: https: //www.mzp.cz/C125750E003B698B/en/waste_management/\$FILE/Waste\%20Act_1852001.pdf (accessed on 20 November 2020).

63. Alvarez-Gil, M.J.; Burgos-Jimenez, J.; Cespedes-Lorente, J.J. An analysis of environmental management, organizational context and performance of Spanish hotels. Omega 2001, 29, 457-471. [CrossRef]

64. European Commission. Available online: http://ec.europa.eu/index_en.htm (accessed on 15 November 2020).

65. Scholz, P. Ecological management in a hotel. Top Hotel. 2016, 10, 128-132.

Publisher's Note: MDPI stays neutral with regard to jurisdictional claims in published maps and institutional affiliations.

(C) 2020 by the authors. Licensee MDPI, Basel, Switzerland. This article is an open access article distributed under the terms and conditions of the Creative Commons Attribution (CC BY) license (http://creativecommons.org/licenses/by/4.0/). 